\title{
Challenges and opportunities for Spatial Data Infrastructure development in Mozambique
}

\author{
ALI AHAMED PUNA ATUMANE \\ Faculdade de Economia e Gestao, Universidade Catolica de Mocambique, Beira, \\ Mozambique \\ NOVA IMS, Universidade Nova de Lisboa, Campus de Campolide, Lisboa, Portugal \\ PEDRO CABRAL \\ NOVA IMS, Universidade Nova de Lisboa, Campus de Campolide, Lisboa, Portugal
}

This is the Accepted Author Manuscript of the article published by Taylor \& Francis in Journal of Map and Geography Libraries:

Atumane, A. A. P., \& Cabral, P. (2019). Challenges and Opportunities for Spatial Data Infrastructure Development in Mozambique. Journal of Map and Geography Libraries, 15(1), 7-27. https://doi.org/10.1080/15420353.2019.1661932 


\section{Challenges and opportunities for Spatial Data Infrastructure development in Mozambique}

The importance of access to spatial data for development and resource management is widely acknowledged worldwide. Unrestricted, reliable and efficient access to accurate, timely, and up-to-date spatial data may be achieved through a Spatial Data Infrastructure (SDI). Thus, most developed countries implemented and continue to develop their SDI. In Africa, there is a growing number of governments committed to SDI development. This paper aims to contribute to initialize an SDI in Mozambique. We identified and characterized through a survey the government institutions producing, sharing, and using spatial data in the country to estimate their potential contribution to the development of the Mozambican SDI. We found 12 institutions producing 15 thematic datasets which can constitute the core of the SDI for Mozambique. Two government agencies have the technical skills and policies to make spatial data available to the public. Based on the possible contribution of these institutions, this paper proposes an SDI for Mozambique based on four pillars: i) organizational framework; ii) legal framework; iii) technical framework; and iv) accessibility.

Keywords: Spatial Data Infrastructure; Geographical Information Systems; Africa; Mozambique

\section{Introduction}

The development of SDI in Africa has long been a concern of the United Nations Economic Commission for Africa (ECA 2003). Successive Committees on Development Information, Science and Technology, have been promoting SDI initiatives in the continent including the publication of the African SDI Handbook by CODIST (ECA 2003). The “African Action Plan on Global Geospatial Information Management 2016-2030" is now in effect with the mission of ensuring the African production and use of authoritative and evidence-based geospatial information to attain its sustainable development goals (United Nations. Economic Commission for Africa 
and UNECA 2017). Other international initiatives, such as the "Network for Cooperative Management of Environment Information and Geospatial Data - EIS Africa", have been raising the awareness of geospatial data stakeholders to the advantages of using common data architectures, providing training and datasets to promote the capacity to generate, manage and disseminate geospatial data in Africa (EIS Africa 2018; UNECA 2003).

The International Conference on Spatial Information for Sustainable Development published the Nairobi Statement, consisting of a set of recommendations for African governments, international organizations and market participants, to ensure the development of consistent and compatible SDI for Africa (Foster and Ryttersgaard 2001). The first recommendation for African governments willing to develop an SDI is the constitution of a Steering Group (SG) to promote the effective partnership and cooperation among the various spatial data stakeholders in the country (Foster and Ryttersgaard 2001). SG have been instrumental in the successful implementation of SDI in South Africa and Namibia (Sinvula et al. 2017), two neighbouring countries of Mozambique. Both countries initiated their road to SDI by forming committees to address technical and institutional issues to allow for the efficient and effective share of spatial datasets among government organizations. This hands-on strategy, named "product-based" approach to SDI development, is the foundation of most of the thriving SDI now in force (Rajabifard et al. 2002). Sharing existing resources and building collaborations between institutions may sort out the basic technical questions and other barriers to data sharing (Akinyemi and Uwayezu 2011), and ensure the SDI is responding to users' needs (Foster and Ryttersgaard 2001; Hendriks et al. 2012). Parallel to the "product-based" strategy, there is the "process-based" strategy focusing on the communication channels to foster awareness, knowledge, and alignment among 
spatial data stakeholders to promote the SDI (Rajabifard et al. 2002). These strategies are complementary and can be delivered by the SG which is composed by the main stakeholders of the spatial information community that will discuss the products and services to be delivered by the SDI (Rajabifard et al. 2006). The SG can also provide a forum for the development of communication channels, organization, leadership and interorganizational cooperation, decisive to the success of the SDI initiative.

The importance of wide access to spatial data and geographical information for development and resources management is widely acknowledged by the scientific community and policymakers (Foster and Ryttersgaard 2001; Makanga and Smit 2010). The digitalization of spatial data and the advances in Information and Communication Technologies (ICT), led many non-specialised users to collect, use and replicate spatial data for their own purposes. However, inconsistencies and incompatibilities among spatial datasets impede their integration and re-use hindering the effective and efficient use of spatial data (Mwange et al. 2018). Kong (2015) while exploring the best management practices of geospatial data in academic libraries has reviewed the common challenges of spatial data management and curation, which includes the application of big data, the emergence of web GIS, and the advancement of cyberinfrastructures, and conceptual framework (Schweers et al. 2016).

The role of a spatial data infrastructure (SDI) is "to provide an environment in which all stakeholders, both users, and producers, of spatial information, can cooperate with each other in a cost-efficient and cost-effective way to better achieve organizational goals" (Rajabifard et al. 2002). Several SDI definitions can be found depending on the context and type of organization (OSGEO 2017; US President 1994; GSDI 2012). In fact, there are so many definitions of SDI that Hendriks et al. (2012) 
classified them in two categories: those focusing in SDI components such as technology or human resources; and those listing SDI objectives to enable better utilization of spatial data and associated services. Still, for every SDI, the concepts of maximization of geographical information use, government coordination, user-driven, and the involvement of technical, organizational and financial issues, and human resources in the implementation should always be present (Masser 2005).

The significant investment required for establishing an SDI can be readily recovered by the gains in efficiency and effectiveness for public servants alone (Lance and Bassolé 2006). Other benefits include increased opportunities for qualified jobs in technology and research, and more resources made available for less wealthy users, such as small municipalities and small businesses. SDI can also contribute to a more efficient and transparent government due to the increasing availability of authoritative data for policy and decision makers (Yalcin 2014).

Recently SDI emerged for social sciences (Schweers et al. 2016). However, environmental protection and natural resources management have been presented as one of the main reasons for implementing national and global SDI (Guigoz 2015; Foster and Ryttersgaard 2001). Environmental issues rarely conform with national, or even regional borders and their management often requires the integration of multiple data and sciences to be effective (UNECA 2017). The environment is clearly pointed as one of the main reasons for the legal enforcement of regional SDI (INSPIRE 2004; US President 1994).

SDI initiatives exist at regional and global levels to address technical issues and legal or administrative arrangements to promote spatial data sharing (GSDI 2015; INSPIRE 2004; PCGIAP 2009; UNECA 2003). In all cases, SDI is meant to provide 
users with complete, compatible, up-to-date, consistent and well documented spatial datasets, coming from different data providers. This requires not only the availability of those datasets, technologies, and skills for its production and dissemination but also the organization, cooperation, and coordination of all spatial data stakeholders, such as government agencies, the private sector, research institutions and other organizations (Coleman and McLaughlin 1998).

In Africa, there is a fast-growing list of countries at an advanced stage of implementation of SDI such as South Africa, Senegal, Rwanda, Nigeria (Ayanlade et al. 2008), Cape Verde (República de Cabo Verde 2010), Namibia, Ghana (Sinvula et al. 2017), with many others on their way. However, many African countries still have insufficient or inadequate infrastructures to manage and disseminate spatial data (Guigoz 2015) as is the case of Mozambique.

This study aims at contributing to the beginning of Mozambique SDI by assessing the capabilities and insufficiencies of the main spatial data stakeholders in the country in what concerns their resources and policies. For this purpose, we surveyed all the Mozambique administrative institutions implied in spatial data production and use, from March to August 2016, to assess their communication and technologic capabilities (including skilled personnel), and the readiness of their data and policies concerning spatial data sharing. Other authors have acknowledged the importance of consulting spatial data stakeholders to identify the main obstacles to spatial data share and exchange at National level (Akinyemi and Uwayezu, 2011). In this study, we take one step further by conceptualising the development of the SDI for Mozambique. This conceptualization is carried out according to international recommendations (Foster and Ryttersgaard 2001), and considering the experience of neighbouring countries and the 
particularities of Mozambique administration (Sinvula et al. 2017). Specifically, the objectives of this paper are:

- Identify the level of potentially useful existing competencies within the government administration for the implementation of the SDI for Mozambique;

- Determine the possible contribution of each government institution; and

- Propose a framework for the initiation and the development of an SDI for Mozambique.

\section{Spatial Data Infrastructures in Africa: the case of Mozambique}

Mozambique is a southern African country bordered by Tanzania in the North, Malawi, Zambia, Zimbabwe, and South Africa in the West, Swaziland, and South Africa in the South, and the Indian Ocean in the East (Figure 1). The country has $799.380 \mathrm{~km}^{2}$ with over 28 million inhabitants (INE 2018), and a coastline of more than $2400 \mathrm{~km}$.

[Figure 1 goes here]

Figure 1. Map of Mozambique with surrounding countries. The inset shows the placement of Mozambique in Africa Continent

The Republic of Mozambique is administered by the central government located in the capital Maputo. The country is hierarchically subdivided into 11 provinces, covering 53 municipalities containing 154 districts. Regional and local 
administrations have a minimal level of autonomy. Government agencies are also largely dependent on central government, and generally operate across the whole country, with little or no dependence to local administrations.

Mozambique is in the $180^{\text {th }}$ position of the Human Development Index, of the 198 countries ranked (OECD 2017). With a Gross Domestic Product per capita just above 100 USD, it is understandable that the development of an SDI has not been prioritized. Mozambique has been attracting foreign investment for its extractive industries and cash crops, both export oriented and with a strong territorial implementation (OECD 2013). Its economic growth remains lower than expected to improve the living conditions of the growing population, also because of the poor state of its domestic physical infrastructures that are hindering the development of the internal market and regional development (OECD 2013). On the other hand, the government is committed to the preservation of the valuable natural ecosystem services (Natural Capital Coalition 2018). The development of the Mozambican SDI must be brought to political attention to assist the government in negotiating among these important but sometimes conflicting objectives.

In Mozambique, there have been attempts to make spatial datasets available on the Internet, such as the "WebGIS Moçambique" prepared by the Brazilian state-owned Agriculture Research Corporation which brings together 14 spatial datasets from national and international institutions (Bolfe et al. 2011). Another initiative was the SDI for the Zambezi valley, in which a spatial and alphanumerical centralized database was made available to monitor sectoral activities using a WebGIS interface (Painho et al. 2015). However, these initiatives are no longer available on the Internet probably due to the end of project funding. The National Cartography and Remote Sensing Centre 
(CENACARTA) provides baseline GIS data, facilitates the purchase of satellite data, and provides topographic and thematic maps; these services are mainly online. However, the website has regularly been offline due to unknown reasons. Finally, the Ministry of Transport launched the "Inter-agency GIS" for Mozambique through the spatial development program (PED) (Ministério dos Transportes e Comunicações 2016). As far as the authors know, the "Inter-agency GIS" for Mozambique is the only initiative currently available on the Internet. The limited success of these initiatives may be due to the lack of commitment and follow-up by the main spatial data stakeholders in the country, and their loose political support and legal framework.

The lack of updated spatial data has been reported in several studies for Mozambique (Cabral et al. 2017; Niquisse et al. 2017). The existence of an SDI is of utmost importance to carry out reliable monitoring studies required for implementing national policies regarding climate change mitigation (República de Moçambique 2015a), mangrove protection (República de Moçambique 2015b), hydrology management (República de Moçambique 2007), poverty management (República de Moçambique 2011), agriculture (República de Moçambique 2013), and others. The existence of an SDI for Mozambique is also fundamental to unlock the full potential benefits from several Earth Observation programs in place, such as the Africa - EU Partnership of the Global Monitoring for Environment and Security (GMES 2018), the TIGER initiative (ESA 2018), among others.

\section{Data and methods}

An early clarification of roles and responsibilities of the different institutions in the SDI initiation is important for the development of the project (Foster and Ryttersgaard 
2001). A total of 17 Ministries and 14 government agencies were identified as the main users and generators of spatial data in the Mozambican Administration (Annex 1). These institutions have responsibilities in defence, natural resources including energy, agriculture, mapping, disaster management, public infrastructure, and statistics in Mozambique.

To assess the potential contribution of these institutions for the development of the SDI in Mozambique, a questionnaire (Annex 2) was developed focusing on the existing capabilities of the different organizations concerning the main SDI components (Mansourian et al. 2006; Guigoz 2015): organization, legal and technical frameworks and accessibility (Table 1).

Table 1. Survey categories and corresponding SDI (adapted from Mansourian et al. 2006, Rajabifard et al. 2006 and Rajabifard et al. 2002)

[Table 1 goes here]

The "Organization framework" of the SDI proposed here, is meant to provide a conceptual model and a strategic plan for the process-based development of an SDI (Coleman and McLaughlin 1998), to raise awareness of spatial data sharing, to promote partnerships among the organizations involved, and to ensure political and financial support for the SDI development and implementation (Mansourian et al. 2006). Whereas the SG of the Nairobi statement (Foster and Ryttersgaard 2001) extends to all stakeholders in the spatial data community, including those not consulted in this survey, such as academia and the private sector, we focused on the government agencies 
because those are the ones with potential to acquire the authority and political support to lead the initiation of the SDI.

We discriminated the experience of the institution as an indication of its potential contribution to the organization framework. The longer the institution has been involved in spatial data in the public administration the more likely its awareness is of the needs, challenges, and abilities of the spatial data stakeholders. Other infrastructural elements, such as recruitment, training and educational policies that would play an important role within and between organizations (Dessers et al. 2009) were not considered due to the lack of information.

The contributions for the Technical Framework and Accessibility of the SDI, or the "product-based" development strategy (Coleman and McLaughlin 1998), are relatively straightforward, as it accounts for the in-house resources that each institution owns, allowing it to provide data and services to the spatial data community.

The data collection process took about 6 months and started with a formal request within the Ministries. The survey was only conducted upon approval of the Ministry which required considerable efforts (e.g., in some cases an appointment with the Permanent Secretary within the Ministries was required). Answers were analyzed and discussed with the institutions through follow-up phone calls and/or emails for further clarification, as well as website visits to complement the assessment. 


\section{Results}

\subsection{Survey results}

From the 31 institutions invited to complete the survey, 10 declined or refused to participate (6 ministries and 4 government agencies), and 5 ministries appointed other government organizations already selected to represent them in the survey. Therefore, our questionnaire was completed by 16 institutions. However, 4 of them stated that spatial data is not of core relevance to their activities. Therefore, our analysis covered 12 governmental institutions of Mozambique involved with spatial data (Table 2).

Table 2. Surveyed institutions in this study

[Table 2 goes here]

\section{Organization framework}

The institutions CENACARTA, DNT, DNGM, and IIP have more than 15 years of experience with Geographic Information Systems (GIS). There are three institutions (INAMI, INE, and MAEFP-DNOT) with less than 15 years and more than six years of experience. There are five institutions (ANE, IIAM, INAM, INGC, and PDE) that have less than six years of experience with GIS (Figure 2).

[Figure 2 goes here] 
Figure 2. Experience in working with GIS

\section{Legal framework}

Most of the surveyed institutions share spatial data with other public and private organizations (Figure 3). Only one institution does not share its spatial data due to regulations, four institutions only share spatial data with other public institutions, and the remainder (seven) share their spatial data with both public and private users. Most of the institutions have no price policy for data accessibility (ANE, DNT, INAMI, IIAM, INE, INGC, PDE). Three of the institutions have data pricing policy (CENACARTA, DNGM, INAM), some data are free of charge while access to other data requires users to pay for obtaining them. Some institutions (three) have no clear procedure for data sharing and require a formal request. Usually, spatial data are made available upon a formal reply to the request made in a long process.

[Figure 3 goes here]

Figure 3. Spatial data sharing

\section{Technical framework}

The 12 surveyed institutions produce 15 spatial data themes. The CENACARTA produces nine categories of spatial data equivalent to $60 \%$. Most of the spatial data are 
being produced by more than one institution except statistics and mine resources by INE and INAMI, respectively (Table 3).

Table 3. Spatial data produced by each institution

[Table 3 goes here]

The category "Others" refers to varied spatial data themes, not included in any other category. Most institutions produce datasets with national coverage (eight), while others generate spatial data for specific parts of the country (four). This might mean that these institutions are working in different scales or coverage areas with a duplication of efforts in data production. Most institutions (ten) have their own standards to produce spatial data. These institutional standards are defined by each institution and differ from one institution to another. Only two institutions (IIP and INAM) follow international standards (ISO/TC 211) and use ISO 19115:2003 and ISO/TC 19139:2007 as a standard for metadata production. These institutions share data with international organizations and, for this reason, they use international standards.

The number of skilled GIS staff identified among the surveyed institutions were 220, most of them are found in CENACARTA and DNT (76\%) (Figure 4).

[Figure 4 goes here]

Figure 4. Skilled GIS staff

The technology level is very good for two institutions: PDE and DNT. These have very good ICT infrastructure with a well-equipped GIS department, from data collection tools to easy online accessibility through SIGIT (land information system). 
Four other institutions were rated as good (CENACARTA, DNOT, INE, and INGC). These have very well-equipped GIS departments and are also well-equipped with ICT to make their data easily accessible online. The remainder are considered adequate due to some insufficiencies in the equipment for both ICT and GIS.

\section{Accessibility}

Spatial data is commonly made available for 11 of the 12 institutions. Seven of them make it available on the Internet, but CDs and pen drives are also regularly used. Figure 5 shows the means used to make the data available.

[Figure 5 goes here]

Figure 5. Accessibility types

\section{Discussion}

\subsection{Current status of spatial data sharing in Mozambique}

The legal framework supporting spatial data is essential for SDI development. However, Mozambique has no policy, law or regulation concerning spatial data. African countries owning SDI have set up specific legislation (e.g., South Africa and Cape Verde for instance, have respectively, Act number 54 of 2003 (Republic of South Africa 2004) and Decree-law 55/2010 of 6 of December (República de Cabo Verde 2010).

The SDI's spatial data themes can differ from one country to another. Some African countries, such as South Africa, have ten spatial data themes (Siebritz and Fourie 2015) and Cape Verde has 19 spatial data themes (Instituto Nacional de Gestão de Território 2014). The survey carried out in this study enabled the identification of 15 
categories of spatial data themes within the Mozambican government institutions that can constitute the core datasets for the future SDI (Table 3). This set of geographical themes is quite diverse in nature and can be very useful, or even decisive, for setting up any successful GIS application in Mozambique. Two of the surveyed institutions, PDE and ITC, have the capabilities to host a WebGIS with the resources already in place. Particularly for Mozambique, organizations such as EIS Africa could provide a forum to stakeholders reach agreements and search guidance to reach a coherent set of common spatial themes and procedures like it has done successfully for other countries, such as Uganda, Benin, Madagascar, Ghana, among others (EIS Africa 2018).

The Mozambican institutions currently share spatial data in an environment where there are no common standards in producing the spatial data, no metadata regulations, no data custodianship nor sharing policies. This may also jeopardize future SDI implementation attempts.

\subsection{An SDI framework for Mozambique}

Experience from many countries (Sinvula et al. 2017) has shown that a successful SDI initiative must cover all the dimensions of the SDI conceptual model as adapted from (Mansourian et al. 2006), as well as the five components detailed by (Rajabifard et al. 2002). Whereas data, skills and technologies are necessary to connect people with the data (Rajabifard et al 2002), i.e., the "product-based" approach of the SDI development, these may not be enough to develop and sustain such a system. The "process-based" approach, involving awareness, communication organization, leadership and will, is very often decisive to the success of an SDI initiative and resides in the organization framework of the SDI model concept adapted from Mansourian et al. 2006. 
The results of our survey highlight the potential contributions of 12 government institutions for the four dimensions of the SDI conceptual model: "Organization framework," "Legal framework," "Technical framework," and "Accessibility." Figure 7 shows the institutions that can better contribute to each dimension according to the referred criteria. 
[Figure 6 goes here]

Figure 6. The proposed structure of SDI Framework for Mozambique

The green colour identifies the four SDI dimensions; the orange colour shows the best-placed institutions to contribute to the SDI respective dimension; and, the blue colour represents a schematic SDI conceptual model: guides and specifications required in each dimension (Mansourian et al. 2006). For the "Organization framework" the criteria used to identify the institutions that can better contribute were the institution experience in producing and managing spatial data, and technology capability. The bestplaced institutions in this criterion were the CENACARTA, DNT, DNGM, and IIP which had more than 15 years of experience, MAEFO-DNOT had 11-15 years of experience. Although PED had only six years of experience it had high technology capability and has been consistently promoting the use of spatial data through WebGIS (Ministério dos Transportes e Comunicações 2016). The same institutions were also considered for the "Legal framework" due to the experience and the spatial data themes produced: CENACARTA produced nine data themes; MAEF-DNOT produced six; IIP three data themes; DNGM and DNT one data theme each but had more than 15 years of experience. The skilled staff and produced spatial data themes were used as a requirement for the "Technical framework." For these reasons, the selected institutions were CENACARTA, DNT, and MAEFO-DNOT. For the last dimension, "Accessibility", the selected institutions were according to technology capability and ICT infrastructure; these were CENACARTA, DNT, INE, INGC, and PED. 


\section{Conclusion}

\subsection{Summary of findings and limitations}

Mozambique has the potential to develop and implement an SDI in the short term. The government agencies have the technical capabilities and experience to put this project on the fast track. All the institutions producing or using spatial data can contribute to SDI development were identified: CENACARTA, DNT, IIP, DNGM, and DNOT for "Legal framework"; CENACARTA and DNOT for "Organization" and “Technical" frameworks; and CENACARTA and PDE for "Accessibility". This paper only addressed the government institutions; however other stakeholders, such as private organizations and academia should also be involved to best contribute to the SDI development. We conclude that the country can develop SDI through "process-based" and "product-based" models. There is also a perceived need to expand and enrich the spatial datasets.

This paper contributes with the identification of the potential stakeholders' roles to the development of the national SDI for Mozambique by assessing their capabilities to contribute to this task. Although the results are promising, the methodology presented in this article still needs to be tested in the field to verify its usefulness. Despite the lack of proof of concept, the methodology carried out can be a roadmap for other African nations within a similar context aspiring to develop their own SDI. 


\subsection{Future steps and risks for the Mozambican SDI}

Experiences from other countries indicate that the best way to ensure the success of implementing an SDI is to constitute an SG to promote agreements among the main stakeholders. The SG has the immediate objective of making the existing spatial datasets with fully documented, coherent and compatible formats available, while promoting the communication among the data providers and the awareness of the whole community (Foster and Ryttersgaard 2001; Sinvula et al. 2017). The process of creating an SDI requires a harmonization effort by setting a technical and institutional framework, a clear legal framework, and easy spatial data accessibility. The main challenge is to raise awareness in the use and value of SDI within the stakeholders to endeavour on the SDI development journey. A strong coordination effort must be carried out to move forward successfully with this initiative considering the current political, social, and economic conditions of Mozambique.

The administration and regulation of the SDI should be based on a public mandate with the authority to ensure its efficient and effective use and public availability (United Nations 2004). Government agencies are often among the main users and producers of geospatial data, and sharing spatial data avoids duplication of efforts in data production and avoids gaps, incoherencies, and incompatibilities among the spatial datasets (Akinyemi and Uwayezu 2011). Therefore, the public administration should lead the implementation of SDI accessible through a reliable, up-to-date web site with information about the SDI associated to a WebGIS where users can easily access data in multiple ways (e.g., through downloads and/or web services).

The SG must be formed with a legal mandate to promote the project and formulate the draft legislation to institute the SDI and, therefore, government support 
must be found (Coleman and McLaughlin 1998; Lance and Bassolé 2006). The absence of political involvement has been identified as one of the main obstacles to spatial data sharing and SDI development, as was the case in Rwanda (Akinyemi and Uwayezu 2011) and, as experienced by other countries, the absence of an authoritative legal framework for SDI is a major drawback for the development, implementation, and maintenance of an SDI (Sinvula et al. 2017).

\section{Acknowledgments}

We thank all the Mozambican government institutions that participated in this study, especially the Ministry of Science \& Technology, Higher \& Technical Professional Education (MCTESTP) for the credential to meet the other institutions. The authors would also like to thank the reviewers for their constructive feedback.

\section{References}

Akinyemi, F.O, and E Uwayezu. 2011. "An Assessment of the Current State of Spatial Data Sharing in Rwanda.” IJSDIR 6: 365-387. doi:10.2902/1725-0463.2011.06.art16.

Ayanlade, a., I.O.O. Orimoogunje, and P.B. Borisade. 2008. "Geospatial Data Infrastructure for Sustainable Development in Sub-Saharan Countries.” International Journal of Digital Earth 1 (3): 247-258. doi:10.1080/17538940802149940.

Bolfe, Édson Luis, Mateus Batistella, Davi de Oliveira Custódio, Orlando Inácio Jalane, and Vanessa Silva Pugliero. 2011. "WebGis Moçambique: Organização Das Bases de Dados Espaciais Para a Plataforma GeoServer." Série Documentos 87. Embrapa Monitoramento Por Satélite. Campina: Empraba.

Cabral, Pedro, Gabriela Augusto, Adeoluwa Akande, Anjos Costa, Nelson Amade, Sérgio Niquisse, Ali Atumane, et al. 2017. “Assessing Mozambique's Exposure to Coastal Climate Hazards and Erosion.” International Journal of Disaster Risk Reduction 23 
(August): 45-52. doi:10.1016/j.ijdrr.2017.04.002.

Coleman, David, and John McLaughlin. 1998. "Defining Global Geospatial Data Infrastructure (GGDI): Components, Stakeholders And Interfaces." Geomatica 52 (2): 129-143.

Dessers, E., P. H. Hendriks, J. Crompvoets, and G. Van Hootegem. 2009. “Analysing Organisational Structures and SDI Performance." In 11th GSDI Conference, Rotterdam, the Netherlands, GSDI.

ECA. 2003. "Chapter Three: Geospatial Data Needs Assessment.” In The SDI Handbook for Africa. Addis Ababa, Ethiopia.

http://repository.uneca.org/bitstream/handle/10855/5093/Bib-33547

Add.4.pdf?sequence $=6$.

EIS Africa. 2018. “A Network For The Co-Operative Management Of Environmental And Geospatial Information In Africa.” Accessed November 15. http://www.eis-africa.org.

ESA. 2018. “Tiger Initiative.” Accessed November 12. http://www.tiger.esa.int.

Foster, Robert, and Jes Ryttersgaard. 2001. The Nairobi Statement on Spatial Information for Sustainable Development. Nairobi, Kenya. http://www.fig.net/resources/publications/figpub/pub30/figpub30.pdf.

GMES. 2018. "Global Monitoring for Environment and Security (GMES).” Accessed December 12. https://www.africa-eu-partnership.org/en/projects/global-monitoringenvironment-and-security-gmes.

GSDI. 2012. Spatial Data Infrastructure Cookbook Update. http://gsdiassociation.org/images/publications/cookbooks/SDI_Cookbook_from_Wiki_20 12_update.pdf.

GSDI. 2015. 2015 GSDI Annual Report.

Guigoz, Y. 2015. "Spatial Data Infrastructures in Africa: A Gap Analysis.” Journal of Environmental Informatics. doi:10.3808/jei.201500325.

Hendriks, Paul H.J., Ezra Dessers, and Geert van Hootegem. 2012. "Reconsidering the Definition of a Spatial Data Infrastructure.” International Journal of Geographical Information Science 26 (8): 1479-1494. doi:10.1080/13658816.2011.639301.

INE. 2018. Anuario Estatistico 2017 - Mocambique. Maputo.

INSPIRE. 2004. "Proposal for a Directive of the European Parliament and of the Council Establishing an Infrastructure for Spatial Information in the Community (INSPIRE)." 
Official Journal of the European Union. http://inspire.jrc.it/proposal/EN.pdf.

Instituto Nacional de Gestao de Territorio. 2014. "Infrastrutura de Dados Espaciais de Cabo Verde." Catalogo.

Kong, Nicole Ningning. 2015. "Exploring Best Management Practices for Geospatial Data in Academic Libraries.” Journal of Map \& Geography Libraries 11 (2): 207-225. doi:10.1080/15420353.2015.1043170.

Lance, Kate, and André Bassolé. 2006. "SDI and National Information and Communication Infrastructure (NICI) Integration in Africa." Information Technology for Development 12 (4): 333-338. doi:10.1002/itdj.20051.

Makanga, Prestige, and Julian Smit. 2010. "A Review of the Status of Spatial Data Infrastructure Implementation in Africa.” South African Computer Journal, no. 45: 18-25.

Mansourian, A., A. Rajabifard, M.J. Valadan Zoej, and I. Williamson. 2006. "Using SDI and Web-Based System to Facilitate Disaster Management." Computers \& Geosciences 32 (3): 303-315. doi:10.1016/j.cageo.2005.06.017.

Masser, Ian. 2005. Creating Spatial Data Infrastructures. ESRI Press.

Ministério dos Transportes e Comunicações. 2016. "Programa de Desenvolvimento Espacial: GIS Interinstituicoes."

Mwange, Collins, Galcano Canny Mulaku, and David N Siriba. 2018. "Reviewing the Status of National Spatial Data Infrastructures in Africa." Survey Review 50 (360): 191-200. doi:10.1080/00396265.2016.1259720.

Natural Capital Coallition. 2018. "Mozambique Government To Set Up National Natural Capital Programme.” https://naturalcapitalcoalition.org/mozambique-government-to-setup-national-natural-capital-programme/.

Niquisse, Sérgio, Pedro Cabral, Ângela Rodrigues, and Gabriela Augusto. 2017. "Ecosystem Services and Biodiversity Trends in Mozambique as a Consequence of Land Cover Change.” International Journal of Biodiversity Science, Ecosystem Services \& Management 13 (1): 297-311. doi:10.1080/21513732.2017.1349836.

OECD. 2013. Investment Policy Reviews: Mozambique. OECD Investment Policy Reviews. OECD Publishing. doi:10.1787/9789264203310-en.

OECD. 2017. "Indices of Human Development.” OECD.Stat. https://stats.oecd.org. OSGEO. 2017. “Open Geospatial Consortium.” Accessed April 12. www.opengeospatial.org. 
Painho, M., L.M. Almeida, H. Martins, A. Adelino, and P. Oliveira. 2015. "Spatial Data Infrastructure for the Zambezi Valley (Mozambique)." 15th International Multidisciplinary Scientific GeoConference SGEM 2015, Book 2. doi:10.5593/SGEM2015/B22/S11.134.

PCGIAP. 2009. United Nations Economic and Social Council: Eighteenth United Nations Regional Cartographic Conference for Asia and the Pacific Bangkok, 26-29 October 2009 Item 5 of the Provisional Agenda Report of the Permanent Committee on Geographical Information Sys. Bangkok.

Rajabifard, A., A. Binns, I. Masser, and I. Williamson. 2006. "The Role of Sub-national Government and the Private Sector in Future Spatial Data Infrastructures." International Journal of Geographical Information Science 20 (7): 727-741. doi:10.1080/13658810500432224.

Rajabifard, Abbas, Mary-Ellen F Feeney, and Ian P Williamson. 2002. "Future Directions for SDI Development." International Journal of Applied Earth Observation and Geoinformation 4 (1): 11-22. doi:10.1016/S0303-2434(02)00002-8.

Republic of South Africa. 2004. "Spatial Data Infrastructure Act No 54 of 2003." Government Gazette 464 (113).

República de Cabo Verde. 2010. “Decreto Lei 55/2010 de 6 de Dezembro.” I Série No 47 Boletim Oficial.

República de Moçambique. 2007. “Plano Nacional de Gestão Dos Recursos Hídricos Em Moçambique.” Maputo, Mozambique.

República de Moçambique. 2011. "Plano de Acção Para a Redução Da Pobreza (PARP), 20112014.” Maputo, Mozambique.

https://www.open.ac.uk/technology/mozambique/sites/www.open.ac.uk.technology.moza mbique/files/pics/d130879.pdf.

República de Moçambique. 2013. "Mozambique National Agriculture Investment Plan 20142018 (PNISA).” Maputo, Mozambique.

http://www.resakss.org/sites/default/files/pdfs/Final PNISA Revised Version_0.pdf.

República de Moçambique. 2015a. "Estratégia Nacional de Adaptação e Mitigação de Mudanças Climáticas 2013-2025, Ministério Para a Coordenação Da Acção Ambiental.” http://www.cgcmc.gov.mz/pt/politicas-estrategias/94-estrategia-nacional-de-adaptacao-emitigacao-de-mudancas-climaticas. 
República de Moçambique. 2015b. "Estratégia e Plano de Acção Nacional Para Restauração de Mangal 2015-2020. Ministério Da Terra, Ambiente e Desenvolvimento Rural, Centro de Desenvolvimento Sustentável Para as Zonas Costeiras."

Schweers, Stefan, Katharina Kinder-kurlanda, Stefan Müller, Pascal Siegers, Stefan Schweers, Katharina Kinder-kurlanda, Stefan Müller, Stefan Schweers, and Katharina Kinderkurlanda. 2016. "Conceptualizing a Spatial Data Infrastructure for the Social Sciences: An Example from Germany.” Journal of Map \& Geography Libraries 12 (1): 100-126. doi:10.1080/15420353.2015.1100152.

Siebritz, Lindy-Anne, and Helena Fourie. 2015. "The South African Spatial Data Infrastructure: A Collaborative SDI." Geomatics Indaba, General Paper, 2-10.

Sinvula, Kisco, Serena Coetzee, Antony Cooper, Wiafe Owusu-Banahene, Emma Nangolo, Victoria Rautenbach, and Martin Hipondoka. 2017. "A Comparative Analysis of Stakeholder Roles in the Spatial Data Infrastructures of South Africa, Namibia and Ghana.” International Journal of Spatial Data Infrastructures Research 12: 1-25.

UNECA. 2003. "Third Meeting of the Committe on Development Information (CODI): SubCommittee on Geoinformation: Technical Issues." In The SDI Africa Handbook, edited by ECA, GSDI, EIS-Africa, and ITC, The SDI ha, 1-5. Addis Ababa: CODI.

United Nations. Economic Commission for Africa, and UNECA. 2017. Geospatial Information for Sustainable Development in Africa: African Action Plan on Global Geospatial Information Management 2016-2030. Addis Ababa. UN.ECA. Addis Ababa, Ethiopia.

United Nations. 2004. Republic of Mozambique: Public Administration Country Profile. http://unpan1.un.org/intradoc/groups/public/documents/un/unpan023278.pdf.

US President. 1994. Coordinating Geographic Data Acquisition and Access: The National Spatial Data Infrastructure. Federal Register. https://www.archives.gov/files/federalregister/executive-orders/pdf/12906.pdf.

Yalcin, Guler. 2014. "Initial Organizational Studies on National Spatial Data Infrastructure at Government Level." Procedia Technology 12: 572-576. doi:10.1016/j.protcy.2013.12.531. 